\title{
Czasopisma naukowe Filii AWF w Białej Podlaskiej w latach 1973-2002
}

\section{Wprowadzenie}

$\mathrm{H}$ istoria bialskiej Filii Akademii Wychowania Fizycznego (dalej: AWF) sięga 1969 r., kiedy zarządzeniem ministra oświaty i szkolnictwa wyższego utworzone zostało w Białej Podlaskiej Wyższe Studium Nauczycielskie (dalej: WSN), będące filią lubelskiego Uniwersytetu Marii Curie-Skłodowskiej$^{1}$. Dnia 1 sierpnia 1970 r. zapadła decyzja o przekazaniu WSN pod opiekuńcze skrzydła warszawskiej AWF. Akademia bialska stała się wówczas jedyną wyższą szkołą wychowania fizycznego działającą po prawej stronie Wisły. Dziekanem filii został dotychczasowy kierownik WSN dr Erazm Wasilewski². W 1982 r. weszła w życie nowa ustawa o szkolnictwie wyższym, zgodnie z którą dotychczasową filię przekształcono w Zamiejscowy Wydział AWF Warszawa z siedzibą w Białej Podlaskiej. W 1988 r. uczelnia zaczęła funkcjonować jako Instytut Wychowania Fizycznego i Sportu ${ }^{3}$.

W historię bialskiej Filii Akademii Wychowania Fizycznego wpisały się dwa wydawnictwa ciągłe - „Zeszyt Naukowy”, przekształcony następnie w „Zeszyt Naukowo-Metodyczny”, i „Rocznik Naukowy”. Pierwsze z nich powołane zostało w 1973 r. - ukazał się wówczas jeden zeszyt tego

${ }^{1}$ H. Mierzwiński, XXX lat AWF w Białej Podlaskiej, „Rocznik Naukowy”, t. 7: 2000, s. 10.

2 E. Wasilewski, Bialska Akademia Wychowania Fizycznego, [w:] Od Akademii Bialskiej do AWF, pod red. M. Kowalskiego, Międzyrzec Podlaski 1973, s. 25-38.

3 M. Brodawska, Duma Bialczan, „Słowo Podlasia” 2000, nr 37, s. 1, 11. 
pisma. Opublikowany w 1974 r. numer drugi nosił już zmieniony tytuł. W tymże roku zostało wydane siedem zeszytów, ale w 1975 r. ich liczba spadła do trzech. Wszystkie zeszyty zostały wydrukowane w Wojewódzkiej Spółdzielni Pracy „Intrograf” w Lublinie. Numer 3 z 1975 r. był ostatnim numerem tego pisma. Jednak w 1993 r. Instytut Wychowania Fizycznego i Sportu (dalej: IWFiS) wspólnie z Wojewódzką i Miejską Biblioteką Publiczną w Białej Podlaskiej (dalej: WiMBP) podjęli kolejną inicjatywę wydawniczą, tym razem był to „Rocznik Bialskopodlaski”. Współpraca IWFiS z WiMBP nie trwała długo, w 1995 r. IWFiS (od 2001 r. Zamiejscowy Wydział Wychowania Fizycznego) zaczął bowiem samodzielnie wydawać drugie własne czasopismo - „Rocznik Naukowy”.

\section{Cechy formalne czasopism}

W ydawcą tomu 1 (1995) była Podlaska Oficyna Wydawnicza „RapidPress" mieszcząca się przy ul. Warszawskiej 13, natomiast drukiem zajęła się firma „artonic” z siedzibą przy ul. Pokoju w Białej Podlaskiej. Jednak już w 1996 r. sytuacja ta uległa zmianie - skład pisma powierzono firmie KWADRAT z ul. Pocztowej 2, drukiem zaś zajęła się drukarnia Stamp\&Print znajdująca się przy ul. Niemcewicza 13. Kolejne zmiany dotyczące druku nastąpiły w 1998 r., drukarnia zmieniła bowiem adres, przenosząc się na ul. Narutowicza 25. Natomiast od 2000 r. opracowaniem i realizacją tekstu zajęła się Oficyna Wydawnicza „Dontech” sp. z o.o., mieszcząca się przy ul. Piłsudskiego 17.

W 1998 r. wydane zostały dwa tomy rocznika - 4 i 5; tom 5 ukazał się w angielskiej wersji językowej, nie był jednak przedrukiem tomu 4. Podobne zjawisko wystąpiło w 1999 r., wtedy bowiem obok tomu 6 wydano suplement $\mathrm{nr} 1$ zatytułowany Uwarunkowania rozwoju fizycznego dzieci i młodzieży szkolnej. Był to numer monograficzny, a okazją do jego wydania była 30. rocznica utworzenia Instytutu Wychowania Fizycznego i Sportu w Białej Podlaskiej. Jak wskazywał tytuł suplementu, został on poświęcony wynikom i materiałom z badań prowadzonych przez wiele polskich ośrodków naukowych dotyczących rozwoju fizycznego dzieci i młodzieży, tempa dojrzewania biologicznego, sprawności i wydolności fizycznej. Wyniki tych badań zreferowali pracownicy naukowi z 18 uczelni i instytutów ${ }^{4}$.

\footnotetext{
${ }^{4}$ Od redakcji, „Rocznik Naukowy”, t. 6: 1999, suplement nr 1, s. 7.
} 
„Zeszyt Naukowy”, wychodzący następnie pt. „Zeszyt Naukowo-Metodyczny", miał postać powielanego maszynopisu. Był to nieoficjalny organ bialskiej Filii AWF, gdyż uczelnia ta jako jednostka niesamodzielna nie posiadała praw wydawniczych. Nadto sytuację utrudniał brak środków finansowych, brak na miejscu oficyny wydawniczej i fakt, że bialska uczelnia była wówczas dopiero raczkującą placówką. Mimo tych trudności znalazły się osoby, które zechciały realizować to przedsięwzięcie. Głównym inicjatorem periodyku był specjalista od spraw higieny i odżywiania doc. dr Jerzy Szczepański, a pomagali mu m.in. pedagog, historyk oświaty i wychowania oraz organizator szkolnictwa wyższego w Zamościu i Białej Podlaskiej doc. dr Wiesław Romanowski, specjalista w dziedzinie opieki nad dzieckiem i wychowania pozaszkolnego doc. dr hab. Kazimierz Czajkowski, doc. dr Antoni Olszowski i doc. dr Juliusz Czaplicki ${ }^{5}$.

\section{Redaktorzy}

$\mathrm{C}^{2}$ zasopismo „Zeszyt Naukowo-Metodyczny” nie miało komitetu redakcyjnego w dzisiejszym tego słowa znaczeniu. Ukazanie się poszczególnych tomów zależało przede wszystkim od zaangażowania autorów publikacji ${ }^{6}$, stąd też w stopce redakcyjnej zawarte były jedynie fragmentaryczne wiadomości dotyczące składu zespołu redakcyjnego. Informacje takie znalazły się w zeszycie 1 z 1973 r., 2, 7 i 8 z 1974 r. oraz 3 z 1975 r. Redaktorem czterech pierwszych zeszytów był inicjator i założyciel pisma Jerzy Szczepański. W ostatnim zeszycie - 3 z 1975 r., przewodniczącym zespołu redakcyjnego był Antoni Olszowski, w skład zespołu wchodzili zaś przedstawieni wyżej K. Czajkowski, J. Czaplicki i J. Szczepański; funkcję sekretarza pełnił dr Józef Drabik - autor licznych prac z zakresu aktywności fizycznej.

W przypadku „Rocznika Naukowego” jego redakcyjnemu kolegium przewodniczył dr hab. Ryszard Cieśliński, prof. AWF, którego prace badawcze koncentrowały się głównie wokół różnych aspektów zawodu nauczyciela wychowania fizycznego. W latach 1995-2000 funkcję zastępcy przewodniczącego kolegium pełnił nauczyciel akademicki i rektor Państwowej Wyższej Szkoły Zawodowej Józef Bergier. W 2001 r. funkcję zastępcy przejął specjalista rozwoju fizycznego i sprawności fizycznej Jerzy

\footnotetext{
${ }^{5}$ Relacja R. Cieślińskiego z dnia 21 kwietnia 2004 r. Notatki w posiadaniu autorki. 6 Tamże.
} 
Sadowski. Przez cały omawiany okres obowiązki sekretarza naukowego pełnił znawca dziejów Podlasia i wojny polsko-bolszewickiej prof. Henryk Mierzwiński. Obok wymienionych osób kolegium redakcyjne w latach 1995-2002 tworzyli: Janusz Jaszczuk - biomechanik, Tomasz Demidowicz - specjalista w zakresie historii nowożytnej, ustroju państwa i prawa oraz historii sportu, Władysław Jagiełło - ekspert w dziedzinie szkolenia judoków, Maciej Skład - zajmujący się problematyką wpływu czynników dziedzicznych i środowiskowych na tempo dojrzewania biologicznego dzieci i młodzieży, Tadeusz Zaradkiewicz - specjalista teorii wychowania fizycznego oraz środowiskowych uwarunkowań sprawności fizycznej dzieci i młodzieży, Romuald Stupnicki - biochemik, endokrynolog i fizjolog, Helena Popławska - znawca rozwoju fizycznego dzieci i młodzieży wiejskiej, oraz Grzegorz Raczyński - ekspert w dziedzinie żywienia człowieka i promocji zdrowia. Na stanowisku sekretarza administracyjnego od 2001 r. pracowała Urszula Jarząbkowska - główny specjalista ds. nauki w Zamiejscowym Wydziale Wychowania Fizycznego w Białej Podlaskiej.

\section{Analiza treści czasopism}

7 asadniczym celem naukowych pism wydawanych przez uczelnie wyżLsze jest umożliwianie pracownikom naukowym publikowania wyników ich badań. Tak też było w przypadku periodyków bialskiej AWF. Omawiane pisma były odzwierciedleniem kierunków badań tamtejszego środowiska. Dlatego też przy analizie treści zostały one potraktowane jako całość, a podział wprowadzono ze względu na podejmowane w nich zagadnienia. I tak wyodrębniono trzy grupy tematyczne: edukacja, szkolnictwo i ruch naukowy; kultura fizyczna, higiena, profilaktyka; ekologia i turystyka.

Zagadnienie edukacji, szkolnictwa i ruchu naukowego poruszano przede wszystkim w kontekście uczelni bialskiej i innych placówek o podobnym charakterze. Pojawiały się również artykuły o tematyce wykraczającej poza ten obszar. 0 problemach całego systemu szkolnego pisała Maria Zydlewska ${ }^{7}$. Kwestię wychowania fizycznego i modelu nauczyciela tego przedmiotu poruszali w swoich pracach Stanisław Ara-

${ }^{7}$ M. Zydlewska, O niektórych problemach aktualnej reformy ustroju szkolnego w Polsce, „Zeszyt Naukowo-Metodyczny” 1974, nr 7, s. 61-67. 
symowicz, Barbara Ignar-Galinowska i Agnieszka Kucharska oraz Zofia Kubińska i Barbara Bergier ${ }^{8}$. W periodykach zwracano uwagę na uczestnictwo dzieci niepełnosprawnych w różnych strefach działalności bialskich szkół podstawowych, rolę i znaczenie szkoły w propagowaniu turystyki wśród dzieci i młodzieży, znaczenie zabawy w nauczaniu dzieci najmłodszych. Nie pominięto również problemu działalności kulturalno-oświatowej w placówkach wczasowych, estetyki szkół podstawowych, roli książki w kształtowaniu osobowości człowieka i kształtowania uzdolnień uczniów klas wyższych szkoły podstawowej ${ }^{9}$. Drukowane w „Roczniku Naukowym” materiały zapoznawały z opiniami nauczyciela o swym zawodzie i uwarunkowaniami decyzji wyboru tego rodzaju pracy ${ }^{10}$. 0 roli nauczyciela wychowania fizycznego pisał Stanisław Arasymowicz, który przedłożył propozycje unowocześnienia tego rodzaju pracy. Na ten temat wypowiadał się również Cieśliński, który przedstawił drogę do tego zawodu i pierwszy kontakt pedagoga ze szkołą ${ }^{11}$.

8 S. Arasymowicz, Propozycja modelowa szkoły o profilu sportowym, „Zeszyt Naukowo-Metodyczny" 1974, nr 3, s. 1-12; B. Ignar-Galinowska, A. Kucharska, Nauczyciele prowadzacy wychowanie fizyczne w szkołach wiejskich, ich kwalifikacje i realizacja tego przedmiotu, „Rocznik Naukowy”, t. 6: 1999, suplement nr 1, s. 505-514; Z. Kubińska, B. Bergier, Postawy nauczycieli wychowania fizycznego wobec reformy edukacji, „Rocznik Naukowy”, t. 9: 2002, s. 301-310.

9 D. Żbikowska-Romanowska, Działalność kulturalno-oświatowa w placówkach wczasowych, „Zeszyt Naukowy” 1973, z. [1], s. 183-197; K. Czajkowski, Pedagogika wczasów dziecięcych - integralna część pedagogiki społecznej, „Zeszyt Naukowo-Metodyczny” 1974, nr 6, s. 37-52; T. Skorupka, O barwie w szkole, „Zeszyt Naukowo-Metodyczny” 1974, z.b3, s. 115-127; M. Ujma, Rola książki w kształtowaniu osobowości współczesnego człowieka, „Zeszyt Naukowo-Metodyczny” 1974, nr 3, s. 129-151; K. Czajkowski, Kształtowanie uzdolnień uczniów klas niższych szkoły podstawowej, „Zeszyt Naukowo-Metodyczny” 1975, nr 3, s. 137-156; K. Włostowska, Uczestnictwo dzieci niepełnosprawnych w różnych sferach działalności bialskich szkół podstawowych, „Rocznik Naukowy”, t. 3: 1997, s. 75-83; J. Żbikowski, G. Godlewski, Rola i zadania szkoły w wychowaniu do turystyki dzieci i młodzieży (badania sondażowe), „Rocznik Naukowy”, t. 7: 2000, s. 281-294; W. Lech-Kurpeta, Ze studiów nad zabawą dziecka - zabawa a sztuka, „Rocznik Naukowy”, t. 6: 2002, s. 349-362.

${ }_{10}$ R. Cieśliński, Opinie nauczyciela wychowania fizycznego o własnym zawodzie, „Rocznik Naukowy”, t. 8: 2001, s. 93-114; K. Włostowska, M. Zajkowska-Magier, R. Wasilewski, Uwarunkowania decyzji wyboru zawodu nauczyciela wychowania fizycznego, „Rocznik Naukowy”, t. 6: 1999, s. 21-35.

11 S. Arasymowicz, Propozycje unowocześnienia działalności wychowawcy fizycznego, „Zeszyt Naukowo-Metodyczny” 1974, nr 7, s. 5-28; tenże, Propozycje unowocześnienia działalności wychowawcy fizycznego, „Zeszyt Naukowo-Metodyczny” 1974, nr 3, s. 13-26; R. Cieśliński, Droga do zawodu nauczycielskiego i pierwszy kontakt ze szkoła, „Zeszyt Naukowo-Metodyczny" 1974, nr 7, s. 29-59. 
Innym tematem często podejmowanym były dzieje, struktura i problemy uczelni wyższych. Pisano o AWF w Białej Podlaskiej ${ }^{12}$, przedstawiono przebieg studiów w Instytucie Wychowania Fizycznego i Sportu w Białej Podlaskiej na tle innych uczelni wychowania fizycznego ${ }^{13}$ oraz podjęto próbę oceny efektywności 4-letniego cyklu studiów magisterskich w IWFiS w Białej Podlaskiej ${ }^{14}$.

Szeroko zajmowano się także społecznością studencką i absolwentami bialskiej uczelni. Przeanalizowano umiejętności żaków w korzystaniu $\mathrm{z}$ różnorodnych metod samodzielnego uczenia się, porównano przygotowania kandydatów na studia zaoczne AWF w Warszawie i Białej Podlaskiej, zanalizowano dążenia i losy absolwentów Filii AWF w Białej Podlaskiej, przytaczano ich wypowiedzi dotyczące zatrudnienia po ukończeniu studiów ${ }^{15}$. Omówiono zróżnicowanie osobowości młodzieży rozpoczynającej i kończącej studia ${ }^{16}$. Zaprezentowano też wybrane aspekty studiowania w Zamiejscowym Wydziale Wychowania Fizycznego w Białej Podlaskiej w opinii studentów, podjęto próbę rozpoznania zainteresowań młodzieży studiującej zagadnieniami małżeństwa i życia rodzinnego oraz zwrócono uwagę na pozytywne i negatywne strony śródrocznych praktyk studenckich ${ }^{17}$.

${ }^{12}$ H. Mierzwiński, XXX lat AWF w Białej Podlaskiej, „Rocznik Naukowy”, t. 7: 2000, s. 7-16.

${ }^{13}$ K. Buchta, Przebieg studiów w IWFiS w Białej Podlaskiej na tle innych uczelni wychowania fizycznego, „Rocznik Naukowy”, t. 9: 2002, s. 87-103.

${ }_{14}$ Taż, Ocena efektywności 4-letniego cyklu studiów magisterskich w IWFiS w Białej Podlaskiej, „Rocznik Naukowy”, t. 4: 1998, s. 5-10.

15 A. Brojek, Umiejętność studiowania studentów pierwszego roku uczelni wychowania fizycznego jako czynnik procesu adaptacji do studiów, „Rocznik Naukowy”, t. 8: 2001, s. 73-92; taż, Umiejętność studiowania w korzystaniu z różnorodnych metod samodzielnego uczenia się, „Rocznik Naukowy”, t. 7: 2000, s. 239-251; M. Zajkowska, Przygotowanie kandydatów na studia zaoczne w AWF w Warszawie i Białej Podlaskiej, „,Rocznik Naukowy”, t. 9: 2002, s. 23-44; D. Tymoszuk, Z badań nad losami pierwszych absolwentów WSN - Filii UMCS, a obecnej Filii AWF w Białej Podlaskiej, „Zeszyt Naukowo-Metodyczny” 1975, z. 2, s. 129-144; T. Lisicki, K. Buchta, Absolwenci uczelni wychowania fizycznego w Białej Podlaskiej i Gdańsku o swoim zatrudnieniu bezpośrednio po ukończeniu studiów, „Rocznik Naukowy", t. 7: 2000, s. 207-219.

${ }_{16}$ M. A. Turosz, Zróżnicowanie osobowości młodzieży rozpoczynającej i kończq̨cej studia w IWFiS w Białej Podlaskiej, „Rocznik Naukowy”, t. 4: 1998, s. 113-121.

${ }_{17}$ J. Sikora, K. Buchta, Wybrane aspekty studiowania w ZW WF w Białej Podlaskiej w opinii studentów, „Rocznik Naukowy”, t. 9: 2002, s. 105-113; K. Włostowska, Małżeństwo i życie rodzinne w świadomości studentów uczelni wychowania fizycznego, „Rocznik Naukowy”, t. 2: 1996, s. 131-141; M. Zajkowska-Magier, K. Włostowska, Niekonwencjonalna forma praktyk pedagogicznych studentów IWFiS w Białej Podlaskiej, „Rocznik Naukowy", t. 6: 1999, s. 47-58. 
Przedstawiono również szereg materiałów z zakresu metodyki. Publikowano propozycje programowe dotyczące kształcenia kadr nauczycielskich, omówiono politykę placówek informacyjno-dokumentacyjnych w wyższej szkole na prowincji ${ }^{18}$. Scharakteryzowano motywy przygotowania studentów i drogi ich kształtowania w zakładzie kształcenia nauczycieli, uzasadniano potrzebę wprowadzenia wychowania seksualnego do szkół wyższych, omówiono zróżnicowane procedury kwalifikowania w latach 90. kandydatów na kierunek wychowania fizycznego w warszawskiej $\mathrm{AWF}^{19}$. Cieśliński dokonał analizy doboru młodzieży do Wyższej Szkoły Nauczycielskiej w aspekcie jakościowym i ilościowym, a następnie przedstawił kwestię startu zawodowego jej absolwentów ${ }^{20}$.

Zagadnienie kultury fizycznej, higieny i profilaktyki poruszano w kontekście historycznym oraz w ramach współcześnie prowadzonych prac badawczych. Do tej pierwszej grupy zaliczyć można badania dotyczące wychowania fizycznego w latach międzywojennych w Policji Państwowej, Centralnym Związku Młodzieży Wiejskiej „Siew” i Centralnym Związku Młodej Wsi ${ }^{21}$. Pisano o tradycjach kultury fizycznej na ziemi przemyskiej ${ }^{22}$. Informowano o genezie i działalności Towarzystwa Gimnastycznego „Sokół" i jego oficjalnym organie prasowym ${ }^{23}$. Natomiast o wychowaniu fi-

${ }_{18}$ J. Szczepański, Propozycje programowe odnośnie kształcenia kadr nauczycielskich w wyższych szkołach wychowania fizycznego oraz wyższych szkołach pedagogicznych z zakresu higieny, w świetle wymagań, wynikających z aktualnych potrzeb, „Zeszyt Naukowy” 1973, z. [1], s. 131-136; M. Nekanda-Trepka, Praktyczna działalność placówki informacyjno dokumentacyjnej w wyższej uczelni na prowincji na tle założeń teoretycznych i przepisów prawnych, „Zeszyt Naukowo-Metodyczny” 1974, z. 3, s. 101-114.

19 Tenże, Przygotowanie absolwentów do studiów w Filii AWF, „Zeszyt Naukowo-Metodyczny" 1974, nr 3, s. 53-69; J. Książek, Próba uzasadnienia wprowadzenia wychowania seksualnego w wyższych szkołach wychowania fizycznego, „Zeszyt Naukowo-Metodyczny” 1974, $\mathrm{nr}$ 6, s. 53-82; taż, Procedury kwalifikowania kandydatów na kierunek wychowania fizycznego w warszawskiej AWF w latach 90-tych, „Rocznik Naukowy”, t. 8: 2002, s. 213-229.

20 R. Cieśliński, Dobór młodzieży do WSN, „Zeszyt Naukowo-Metodyczny” 1974, z. 3, s. 27-52; tenże, Wybrane problemy startu zawodowego pierwszych absolwentów WSN, „Zeszyt Naukowo-Metodyczny" 1974, z. 3, s. 71-90.

${ }^{21}$ J. Klimczak, Wychowanie fizyczne i sport w Polskiej Policji Państwowej II Rzeczypospolitej, „Rocznik Naukowy”, t. 2: 1996, s. 153-156; E. Małolepszy, Kultura fizyczna w działalności Centralnego Związku Młodzieży Wiejskiej „Siew” i Centralnego Związku Młodej Wsi w latach 1919-1939, „Rocznik Naukowy”, t. 9: 2002, s. 321-334.

22 K. Warchoł, Tradycje kultury fizycznej na Ziemi Przemyskiej w latach 1918-1939 i po II wojnie światowej do 1975 roku, „Rocznik Naukowy”, t. 8: 2001, s. 31-42.

23 Z. Cicirko, Z działalności Towarzystwa Gimnastycznego „Sokół” na Podlasiu w latach 1918-1939, „Rocznik Naukowy”, t. 7: 2000, s. 221-226; T. Drozdek-Małolepsza, E. Małolepszy, Przyczynek do dziejów Towarzystwa Gimnastycznego „Sokót” w województwie kieleckim w latach 1919-1939, „Rocznik Naukowy”, t. 7: 2000, s. 269-280; A. Górka, „Przewod- 
zycznym w okresie okupacji hitlerowskiej pisali Edward Kospath-Pawłowski, Mirosława Ponczka i Maciej Chicewicz ${ }^{24}$. Czesław Borejsza zajął się powszechną historią sportu, analizował dzieje klubów stowarzyszeń lekkoatletycznych w Europie, począwszy od XIX w. ${ }^{25}$

Dużo uwagi poświęcano różnym dyscyplinom sportowym. Przedmiotem szczególnego zainteresowania stała się gra w piłkę nożną. Na zagadnienie to zwrócił uwagę Józef Bergier, który dokonał wielokierunkowej analizy działań z piłką w czasie Mistrzostw Świata w Piłce Nożnej, przedstawił strukturę gry bramkarza oraz omówił działania ofensywne i defensywne piłkarzy nożnych w turnieju olimpijskim Barcelona '92, a wspólnie z Włodzimierzem Starostą opisał zakres stronnego zróżnicowania w przygotowaniu technicznym piłkarzy nożnych czołowych zespołów Europy i świata ${ }^{26}$. Na temat tej dyscypliny sportowej pisali nadto Aleksander Stuła i Grzegorz Taranowicz ${ }^{27}$.

Mniejszym zainteresowaniem badawczym cieszyły się gry w piłkę ręczną i siatkową. W przypadku tej pierwszej scharakteryzowano treść gry drużyn chłopięcych, a w drugiej - spójność wewnątrzgrupową drużyn żeńskich ${ }^{28}$.

nik Gimnastyczny Sokót” w okresie międzywojennym - strona ideowa i formalno-techniczna, „Rocznik Naukowy”, t. 3: 1997, s. 85-93.

${ }^{24}$ E. Kospath-Pawłowski, Wychowanie fizyczne i sport w szkoleniu bojowym i Armii Wojska Polskiego na froncie, „Rocznik Naukowy”, t. 9: 2002, s. 289-299; M. Ponczek, Kultura fizyczna w myśli narodowej, demokratycznomieszczańskiej i chłopskiej lat wojny i okupacji hitlerowskiej, „Rocznik Naukowy”, t. 7: 2000, s. 199-206; M. Chicewicz, Sport i wychowanie fizyczne jako środek represji w hitlerowskich obozach koncentracyjnych, „Zeszyt Naukowo-Metodyczny" 1974, z. 8, s. 45-76.

${ }^{25}$ C. Borejsza, Powstanie pierwszych klubów i stowarzyszeń lekkoatletycznych $w$ Europie w II połowie XIX i na początku XX wieku, „Zeszyt Naukowo-Metodyczny” 1975, z. 2, s. $41-45$.

${ }^{26}$ J. Bergier, Struktura gry bramkarzy w spotkaniach piłkarskich najwyższej rangi, „Rocznik Naukowy”, t. 1: 1995, s. 111-124; tenże, Analiza działań ofensywnych i defensywnych piłkarzy nożnych w turnieju olimpijskim - Barcelona '92, „Rocznik Naukowy”, t. 2: 1996, s. 27-40; tenże, Wielokierunkowa analiza działań z piłkq w Mistrzostwach Świata w Piłce Nożnej - USA '94, „Rocznik Naukowy”, t. 3: 1997, s. 95-112; W. Starosta, J. Bergier, Zakres stronnego zróżnicowania w przygotowaniu technicznym piłkarzy nożnych czołowych zespołów Europy i świata, „Rocznik Naukowy”, t. 2: 1996, s. 11-26.

27 A. Stuła, Zmienność ontogenetyczna zdolności szybkościowych i koordynacyjnych u młodych piłkarzy nożnych, „Rocznik Naukowy”, t. 3: 1997, s. 113-119; G. Taranowicz, Osobowościowe i społeczne czynniki powodzenia juniorów w piłce nożnej, „Zeszyt Naukowo-Metodyczny" 1974, z. 5, s. 35-67.

${ }^{28} \mathrm{~J}$. Bergier, J. Glinka, Charakterystyka treści gry w piłce ręcznej drużyn młodzieżowych chłopców, „Rocznik Naukowy”, t. 7: 2000, s. 77-93; M. Kuniewicz, H. Mroczkowska, 
$\mathrm{Na}$ temat sportu atletycznego pisali Czesław Borejsza i Władysław Kudelski ${ }^{29}$. Poza tym kilkakrotnie mówiono o sportach walki, trójboju siłowym i skokach na batucie ${ }^{30}$. Kolejnym stałym tematem organów IWFiS w Białej Podlaskiej był sport w opinii różnych środowisk. Stefan Litwiniuk napisał o stosunku do sportu społeczności wiejskiej ${ }^{31}$. 0 postawach uczniów wobec aktywności fizycznej pisali Marek Prokopiuk, Anna Bodasińska i Monika Klimkowska ${ }^{32}$. Znaczeniem aktywności ruchowej dla rozwoju dziecka w placówkach pozaszkolnych zajmowały się i wyniki swoich badań publikowały Danuta Żbikowska-Romanowska i Krystyna Górniak, a Tadeusz Zaradkiewicz analizował sprawność fizyczną uczniów poszczególnych szkół ${ }^{33}$. Zwracano też uwagę na urazowość uczniów na lekcjach wychowania fizycznego i zainteresowania sportem młodzieży pracującej. Ponadto dokonano analizy niektórych emocjonalnych przeżyć kibiców sportowych ${ }^{34}$.

R. Stupnicki, Spójność wewnątrzgrupowa w żeńskich trzecioligowych zespołach piłki siatko$w e j$, „Rocznik Naukowy”, t. 7: 2000, s. 185-198.

${ }_{29}$ C. Borejsza, Z badań nad genezą nowoczesnego sportu atletycznego we Francji $i$ Włoszech, „Zeszyt Naukowo-Metodyczny” 1974, z. 8, s. 3-43; tenże, Walki nowoczesnych zapasów i ćwiczeń siłowych w Szwajcarii, „Zeszyt Naukowo-Metodyczny” 1974, z. 6, s. 1-36; tenże, Z badań nad genezq rosyjskiej atletyki, „Zeszyt Naukowo-Metodyczny” 1975, z. 2, s. 19-39; W. Kudelski, Polscy lekkoatleci - weterani w świetle badań w 1993 r., „, Rocznik Naukowy", t. 3: 1997, s. 121-132.

${ }^{30}$ Zob. np. W. Kudelski, Trójbój siłowy w Polsce do roku 1994, „Rocznik Naukowy”, t. 8: 2001, s. 255-268; W. Jagiełło, Struktura szkolenia ukierunkowanego w Judo, „Rocznik Naukowy”, t. 2: 1996, s. 41-45; A. Czaplicki, Badania dynamiki salta w tył na batucie, cz. 1: „Rocznik Naukowy”, t. 4: 1998, s. 37-44; cz. 2: „Rocznik Naukowy”, t. 5: 1999, s. 155-162.

31 S. L. Litwiniuk, Sport w świadomości społeczności wiejskiej a działalność Kół Zrzeszenia LZS, „Zeszyt Naukowo-Metodyczny” 1975, z. 3, s. 5-14.

32 A. Bodasińska, Postawy uczniów szkół wiejskich wobec sportu i wartości idei olimpijskiej, „Rocznik Naukowy”, t. 8: 2001, s. 167-181; M. Klimkowska, Społeczne uwarunkowania postaw uczniów wobec kultury fizycznej, „Rocznik Naukowy”, t. 8: 2001, s. 53-71; M. Prokopiuk, Realizacja programu nauczania wychowania fizycznego w opinii Gimnazjum w Łomazach, „Rocznik Naukowy”, t. 9: 2002, s. 335-348.

33 D. Żbikowska-Romanowska, Z badań eksperymentalnych w placówkach wczasów dziecięcych, „Zeszyt Naukowy” 1973, z. [1], s. 199-214; K. Górniak, Pierwsza kolonia zdrowotna w Białej Podlaskiej, „Zeszyt Naukowo-Metodyczny” 1975, z. 2, s. 101-111; tenże, M. Bochenek, Sprawność fizyczna uczniów liceum ogólnokształcącego i zasadniczej szkoły zawodowej w Żurominie, „Rocznik Naukowy”, t. 8: 2001, s. 269-280.

${ }^{34}$ W. Kudelski, Zainteresowania młodzieży pracującej Przemysłu Gumowego „Stomil” w Grudziądzu różnymi formami kultury fizycznej w świetle wywiadów, „Zeszyt Naukowo-Metodyczny" 1974, z. 7, s. 89-99; D. Tymoszuk, Próba analizy niektórych przeżyć emocjonalnych kibiców sportowych wybranych studentów Filii AWF, „Zeszyt Naukowo-Metodyczny” 1975, z. 2, s. 145-158; H. Wyciszkiewicz, J. Wyciszkiewicz, Urazowość na lekcjach wychowania fizycznego w szkołach zawodowych w zależności od dyscypliny sportowej, „Zeszyt Naukowo-Metodyczny" 1975, z. 2, s. 183-188. 
Zarówno w „Zeszycie Naukowo-Metodycznym”, jak i w „Roczniku Naukowym” publikowano wyniki badań dotyczących rozwoju fizycznego i sprawności fizycznej młodzieży studiującej. Omówiono m.in. korelacje wybranych cech sprawności lekkoatletycznej i gimnastycznej u studentek Filii AWF, profile zdolności motorycznych kobiet studiujących, stan zdolności motorycznych kobiet, dynamikę kształtowania się wyników trójboju lekkoatletycznego studentek, poziom neurotyczności i lęku, a także sportowe i parasportowe zainteresowania studentów ${ }^{35}$. Porównano miejsce kultury fizycznej w życiu studentów AWF w Białej Podlaskiej i Katolickiego Uniwersytetu Lubelskiego ${ }^{36}$. Kolejne artykuły z tej grupy tematycznej analizujące społeczność akademicką dotyczyły oceny sposobu żywienia studentów, ustalenia wpływu postaw prozdrowotnych na kształtowanie poziomu poczucia sensu życia ${ }^{37}$. Elżbieta Huk-Wieliczuk przedstawiła stan wiedzy studentów na temat zespołu chorobowego HIV i zobrazowała, jak sytuacja ta przedstawia się u młodzieży w wieku 17-23 lat ${ }^{38}$.

Wielokrotnie poruszano zagadnienia fizjologii sportu. Janusz Iskra badał zależność między budową somatyczną a osiągnięciami w sporcie ${ }^{39}$. Juliusz Czaplicki, wraz z innymi specjalistami w tej dziedzinie, podjął

35 J. Drabik, W. Kudelski, Związki wybranych cech sprawności lekkoatletycznej i gimnastycznej u studentów Filii AWF w Białej Podlaskiej, „Zeszyt Naukowo-Metodyczny” 1975, z. 3, s. 75-82; T. Zaradkiewicz, Profil zdolności motorycznych kobiet rozpoczynających studia na uczelni wychowania fizycznego, „Rocznik Naukowy”, t. 6: 1999, s. 129-135; tenże, B. Jadczak, Stan zdolności motorycznych studentek I roku IWFiS w Białej Podlaskiej w latach 1995-1997, „Rocznik Naukowy”, t. 4: 1998, s. 123-130; J. Drabik, Dynamika kształtowania się wyników 3-boju lekkoatletycznego studentek Filii AWF w Białej Podlaskiej na przestrzeni trzech lat studiów, „Zeszyt Naukowo-Metodyczny” 1975, z. 3, s. 57-62; M. Turosz, Neurotyzm i lęk jako właściwości osobowości studentów I roku Instytutu Wychowania Fizycznego i Sportu w Białej Podlaskiej, „Rocznik Naukowy”, t. 1: 1995, s. 43-49; J. Szczepański, Sportowe i parasportowe zainteresowania studentów Filii AWF, „Zeszyt Naukowo-Metodyczny” 1975, z. 1, s. 21-30.

${ }^{36}$ A. Bochenek, Miejsce kultury fizycznej w aktywności samowychowawczej studentów IWFiS w Białej Podlaskiej oraz KUL-u, „Rocznik Naukowy”, t. 9: 2002, s. 7-22.

37 W. Świątek, K. Ziemnicki, Badania ankietowe wybranych zagadnień żywienia studentów AWF Filia w Białej Podlaskiej, „Zeszyt Naukowo-Metodyczny” 1975, z. 2, s. 113-128; K. Włostowska, Poczucie sensu życia a postawy prozdrowotne studentów studiów stacjonarnych i zaocznych IWFiS w Białej Podlaskiej, „Rocznik Naukowy”, t. 9: 2002, s. 67-85.

38 E. Huk, H. Popławska, Wiedza studentów AWF o HIV/AIDS, „Rocznik Naukowy”, t. 1: 1995, s. 65-71; tychże, Stosunek młodzieży w wieku 17-23 lat do HIV/AIDS, „Rocznik Naukowy", t. 2: 1996, s. 143-151.

${ }^{39} \mathrm{~J}$. Iskra, Wpływ budowy somatycznej oraz poziomu szybkości biegowej na rezultaty w biegu przez płotki chłopców, „Rocznik Naukowy”, t. 6: 1999, s. 137-141; tenże, Budowa somatyczna a zmiany rytmu płotkarskiego w biegu na 400 m przez płotki mężczyzn, „Rocznik Naukowy", t. 7: 2000, s. 309-314. 
trud ustalenia zmian fizykochemicznych we krwi pod wpływem wysiłku fizycznego i środków dopingujących. 0 zmianach leukergicznych pisali ponadto Mieczysław Bytniewski, Zdzisława Maciejak, Jan Rybak, Janusz Sklepik i Jacek Salwiński ${ }^{40}$. Pracownicy naukowi AWF w swoich badaniach uwzględniali także wszelkie zachodzące pod wpływem wysiłku fizycznego zmiany w organizmie. Analizowano zachowanie oporności osmotycznej leukocytów, niemiarowość zatokową serca, zmiany poziomu cholesterolu w surowicy krwi, wydzielenie kwasu solnego w soku żołądkowym ${ }^{41}$. Poza tym publikowano materiały traktujące o stanie składu tkankowego ciała, powstawaniu i biologicznej funkcji wolnych rodników tlenowych, znaczeniu otyłości dla wydolności fizycznej, zmianach wydolności krążeniowo-oddechowej u dzieci z wadą postawy, procesach zachodzących w ośrodkowym układzie nerwowym i korelacjach między tempem dojrzewania a rozwojem cech motorycznych ${ }^{42}$. Podejmowano również próby

${ }^{40}$ J. Czaplicki, Zmiany odczynu leukergicznego pod wpływem wysiłku fizycznego $w$ zależności od stopnia wydolności fizycznej, „Zeszyt Naukowo-Metodyczny” 1973, z. 1, s. 1-34; F. Taranowicz, G. Taranowicz, Przyczynek do badań nad odczynem leukergii w warunkach intensywnego treningu lekkoatletycznego u ludzi młodych, „Zeszyt Naukowo-Metodyczny" 1974, z. 5, s. 21-24; J. Czaplicki, J. Szczepański, Badania nad leukergiq w warunkach stosowania środków dopingujących, „Zeszyt Naukowo-Metodyczny” 1974, z. 7, s. 81-87; M. Bytniewski, Wpływ metyloandrostendiolu na wydolność fizycznq sprawdzanq testem leukergicznym, „Zeszyt Naukowo-Metodyczny” 1975, z. 3, s. 83-110; Z. Maciejak, J. Rybak, J. Sklepik, J. Salwiński, Powysiłkowe zmiany leukergiczne u palaczy tytoniu i osób niepalacych, „Zeszyt Naukowy” 1973, z. [1], s. 41-45.

${ }^{41}$ J. Czaplicki, J. Szczepański, Przyczynek do badań nad opornościq osmotyczna leukocytów, „Zeszyt Naukowy” 1973, z. [1], s. 37-40; R. J. Wierak, Niemiarowość zatokowa u młodzieży trenujq̨cej i nie trenujaccej, „Zeszyt Naukowo-Metodyczny” 1975, z. 2, s. 159-182; J. Czaplicki, W. Kudelski, J. Charytoniuk, Zmiany poziomu cholesterolu całkowitego w surowicy krwi treningu lekkoatletycznego u ludzi młodych, „Zeszyt Naukowo-Metodyczny” 1974, z. 3, s. 91-100; J. Szczepański, Badania nad wydzielaniem kwasu solnego w soku żołądkowym w warunkach klinicznych i sportowych, „Zeszyt Naukowo-Metodyczny” 1974, z. 2, s. 7-53.

${ }^{42}$ L. Bukała, Wpływ otyłości na obciążenie i wydolność fizycznq, „Zeszyt Naukowo-Metodyczny" 1975, z. 2, s. 81-92; J. Czaplicki, J. Charytoniuk, Zmiany poziomu niektórych amin biogennych $w$ ośrodkowym układzie nerwowym a sen, „Zeszyt Naukowo-Metodyczny" 1975, z. 1, s. 13-20; J. Czaplicki, Powstawanie i biologiczna funkcja wolnych rodników tlenowych, „Rocznik Naukowy”, t. 3: 1997, s. 27-33; D. Demediuk, A. Saczuk, H. Popławska, Wpływ tempa dojrzewania płciowego u dziewcząt na poziom rozwoju cech motorycznych, „Rocznik Naukowy”, t. 4: 1998, s. 51-64; P. Różański, Zmiany wydolności krążeniowooddechowej dzieci ze skoliozami na przykładzie uczniów Szkoły Podstawowej nr 9 w Białej Podlaskiej, „Rocznik Naukowy”, t. 7: 2000, s. 37-59; J. Saczuk, A. Wasiluk, E. Jówko, J. Czeczelewski, Ocena składu tkankowego ciała studentów IWFiS w Białej Podlaskiej w oparciu o metodę antropometrycznq i bioelektrycznq metodę impedancji, „Rocznik Naukowy”, t. 8: 2001, s. 205-211. 
ustalenia mocy nóg u ciężarowców, możliwości zastosowania biorytmu dla optymalizacji treningu i uzasadniano potrzebę badań wyniku sportowego $^{43}$. Przeprowadzono także analizę znaczenia i skutków stosowania preparatu odchudzającego NORMEKS ${ }^{44}$.

Zwracano także uwagę na stan higieniczno-sanitarny poszczególnych obiektów, w tym placówek szkolno-wychowawczych. Przedstawiono warunki funkcjonowania szkół podstawowych i średnich w Garwolinie oraz stan BHP w fizycznych i chemicznych pracowniach szkół średnich w powiecie bialskopodlaskim ${ }^{45}$. Analizy warunków higieniczno-sanitarnych przeprowadzono też dla obiektów sportowych w powiecie Radzyń Podlaski, na terenie miasta Siedlce i Chełm Lubelski oraz powiatu biłgorajskiego $^{46}$. Dokładnym analizom poddano jednak przede wszystkim obiekty IWFiS w Białej Podlaskiej, badając oświetlenie sal dydaktycznych w budynkach uczelni, a nawet mikroklimat tamtejszych sal sportowych ${ }^{47}$.

Na łamach omawianych czasopism niejednokrotnie naukowej analizie poddawano problemy osób niepełnosprawnych i ich rodzin. Należy tu wymienić artykuły Tadeusza Maszczaka, Wiesławy Białek, Tadeusza Ło-

${ }^{43}$ H. Górniak, Próba zastosowania biorytmów w pracy treningowej z sekcja podnoszenia ciężarów przy KS RAKS w Białej Podlaskiej, „Zeszyt Naukowo-Metodyczny” 1975, z. 2, s. 97-100; J. Drabik, H. Górniak, Próba określenia mocy nóg ciężarowców, „Zeszyt Naukowo-Metodyczny” 1975, z. 3, s. 51-56; J. Drabik, Potrzeba badań wyniku sportowego, „Zeszyt Naukowo-Metodyczny" 1975, z. 2, s. 93-96.

${ }^{44}$ J. Szczepański, J. Czaplicki, Wstępna ocena możliwości, warunków stosowania i przydatności preparatu „NORMEX”, „Zeszyt Naukowo-Metodyczny” 1975, z. 1, s. 31-40.

45 J. Raczyńska, J. Szczepański, Analiza stanu BHP w pracowniach fizycznych $i$ chemicznych szkół średnich powiatu Biała Podlaska, „Zeszyt Naukowy” 1973, z. [1], s. 95-110; J. Walenda, J. Szczepański, Analiza wyposażenia sanitarnego i kontroli lekarskiej w szkołach podstawowych i średnich na terenie miasta Garwolina, „Zeszyt Naukowo-Metodyczny" 1974 , z. 5, s. 70-75.

46 Z. Kałanowski, J. Szczepański, Warunki higieniczno-sanitarne zamkniętych obiektów sportowych na terenie Radzyń Podlaski, „Zeszyt Naukowy” 1973, z. [1], s. 47-56; G. Rostek, J. Szczepański, Ocena stanu sanitarno-higienicznego obiektów sportowych otwartych wraz z zapleczem na terenie miasta Siedlce, „Zeszyt Naukowy” 1973, z. [1], s. 111-129; M. Sikorski, J. Szczepański, Ocena stanu sanitarno-higienicznego otwartych obiektów sportowych na terenie miasta Chełma Lubelskiego, „Zeszyt Naukowo-Metodyczny” 1974, z. 5, s. 25-33; J. Baryła, J. Szczepański, Ocena stanu sanitarno-higienicznego zamkniętych obiektów sportowych na terenie powiatu biłgorajskiego, „Zeszyt Naukowo-Metodyczny” 1974, z. 5, s. 5-20.

47 J. Czeczelewski, E. Huk, Ocena mikroklimatu sal sportowych IWFiS w Białej Podlaskiej, „Rocznik Naukowy”, t. 1: 1995, s. 131-143; J. Czeczelewski, Ocena oświetlenia światłem elektrycznym sal dydaktycznych na terenie IWFiS w Białej Podlaskiej, „Rocznik Naukowy", t. 6: 1999, s. 201-210. 
bożewicza i Jarosława Żbikowskiego ${ }^{48}$. Lucjan Bukała naświetlił niektóre możliwości walki z zaburzeniami rozwojowymi i poruszył problem profilaktyki w poprawie zdrowia populacji. Ten sam autor omówił niektóre zagadnienia sportowo-lekarskie w położnictwie i chorobach kobiecych oraz ukazał wpływ sportu i wychowania fizycznego na przebieg ciąży, porodu i połogu ${ }^{49}$. Natomiast Urszula Parnicka poświęciła szereg artykułów ograniczeniu udziału kobiet w rekreacji przez fakt posiadania dzieci, a także świadomości kobiet w kwestii walorów zdrowotnych ćwiczeń fizycznych i praktycznego ich stosowania ${ }^{50}$.

Szeroko analizowano zagadnienia dotyczące dzieci i młodzieży. Obszernie omówiono problem środowiskowych uwarunkowań rozwoju fizycznego dzieci. Dokonano oceny rozwoju i sprawności fizycznej dziewcząt ze wschodnich województw, porównując je z ich rówieśniczkami z Krakowa, oraz zobrazowano rozwój dziewcząt województwa podlaskiego i lubelskiego z uwzględnieniem stratyfikacji społecznej, omówiono wpływ wielkości rodziny na rozwój dzieci i młodzieży ${ }^{51}$. 0 sprawności fizycznej i rozwoju somatycznym młodzieży przebywającej w zakładzie poprawczym napisał Antoni Olszowski. Natomiast J. Czeczelewski z G. Raczyńskim podjęli próbę oceny żywienia dzieci w różnych grupach wiekowych ${ }^{52}$.

${ }^{48}$ J. Żbikowski, Rekreacja ruchowa i turystyczna jako czynnik społecznej integracji osób niepełnosprawnych, „Rocznik Naukowy”, t. 4: 1999, s. 131-137; T. Maszczak, Wychowanie fizyczne i sport osób niepełnosprawnych w obliczu przemian społecznych, „Rocznik Naukowy”, t. 9: 2002, s. 185-192; W. Białek, Aktywność ruchowa a integracja społeczna w odczuciu niepełnosprawnych, „Rocznik Naukowy”, t. 9: 2002, s. 193-205; T. Łobożewicz, Potrzeby rozwijania wydolności fizycznej osób niepełnosprawnych, „Rocznik Naukowy”, t. 9: 2002, s. 381-383.

49 L. Bukała, Niektóre aspekty możliwości walki z zaburzeniami rozwojowymi, „Zeszyt Naukowy" 1973, z. [1], s. 165-173; tenże, Profilaktyka w poprawie zdrowia populacji, „Zeszyt Naukowy” 1973, z. [1], s. 175-182; tenże, Nowe poglądy na niektóre zagadnienia sportowo-lekarskie w położnictwie i chorobach kobiecych, „Zeszyt Naukowo-Metodyczny” 1975, z. 3, s. 129-136; tenże, Wpływ sportu i wychowania fizycznego na przebieg ciąży, porodu i połogu, „Zeszyt Naukowo-Metodyczny” 1975, z. 2, s. 73-79.

50 Zob. np. U. Parnicka, Bariery aktywności ruchowej kobiet-matek, „Rocznik Naukowy", t. 6: 1999, s. 81-87.

51 J. Saczuk, Rozwój fizyczny i sprawność fizyczna dziewcząt ze wschodnich województw Polski na tle innych środowisk, „Rocznik Naukowy”, t. 1: 1995, s. 73-85; tenże, D. Tarasiuk, Wpływ wielkości rodziny na rozwój fizyczny dzieci i młodzieży w wieku 3-19 lat we wschodnich województwach Polski, „Rocznik Naukowy”, t. 2: 1996, s. 65-78; J. Saczuk, R. Skerczyńska, Rozwój fizyczny dziewcząt zamieszkujących województwa podlaskie i lubelskie z uwzględnieniem stratyfikacji społecznej, „Rocznik Naukowy”, t. 6: 1999, s. 113-127.

52 Zob. np. J. Czeczelewski, G. Raczyński, Częstość spożywania II śniadań przez uczniów klas V-VIII na przykładzie jednej ze szkół podstawowych w Białej Podlaskiej, „Rocznik Naukowy", t. 6: 1999, s. 143-154. 
Na szczególną uwagę zasługuje suplement nr 1 „Rocznika Naukowego", który poświęcono problemom rozwoju fizycznego, tempa dojrzewania biologicznego, sprawności i wydolności fizycznej dzieci ze środowisk wiejskich. Zwrócono również uwagę na zmiany czasowe w podstawowych cechach somatycznych, w wieku menarche i w cechach motorycznych. Nie pominięto też kwestii żywienia młodocianych mieszkańców wsi, stanu ich zdrowia, w tym wad postawy i aparatu ruchu ${ }^{53}$. Autorzy artykułów zajmowali się także takimi kwestiami, jak przyczyny urazów na terenie powiatu Biłgoraj czy higiena pracy kierowców samochodowych ${ }^{54}$.

Na łamach czasopism AWF znajdowały również wyraz badania nad ukształtowaniem powierzchni, bogactwem fauny i flory oraz turystycznymi warunkami regionu. Omówiono klimat, zapoznano z teoretycznymi podstawami terenu i krajobrazu - powstaniem, ewolucją i istotą krajobrazu naturalnego ${ }^{55}$. Wiele miejsca poświęcono badaniom nad stanem wód powierzchniowych i podziemnych. Pisano o roli łowiectwa na tle ochrony środowiska i omówiono związki warunków przyrodniczych z rozwojem agroturystyki. 0 agroturystyce w świetle szans dla polskiej wsi traktowały też prace Danuty Nałęckiej oraz Jacka Sikory i Krystyny Buchty. Sprawę rozwoju turystyki w Białej Podlaskiej poruszyli Grzegorz Godlewski i Jarosław Żbikowski ${ }^{56}$.

53 Więcej zob. „Rocznik Naukowy”, t. 6: 1999, suplement nr 1.

${ }_{54}$ T. Tujaka, J. Szczepański, Analiza przyczyny urazów na terenie powiatu Biłgoraj w latach 1968-1972, „Zeszyt Naukowy” 1973, z. [1], s. 137-164; H. Perłowski, J. Szczepański, Przyczynek do badań nad higienq pracy kierowców pojazdów samochodowych, „Zeszyt Naukowy" 1973, z. [1], s. 87-93.

55 T. Jakubowski, Podstawowe zagadnienia terenu i krajobrazu, „Zeszyt Naukowo-Metodyczny" 1974, z. 4, s. 1-126; R. Szumański, Charakterystyka klimatologiczna regionu Biała Podlaska, „Zeszyt Naukowo-Metodyczny” 1975, z. 1, s. 79-127.

56 M. Szczepański, J. Szczepański, Ochrona środowiska z uwzględnieniem roli łowiectwa, „Zeszyt Naukowo-Metodyczny” 1975, z. 1, s. 41-78; M. Danilkiewicz, Przyrodnicze warunki rozwoju agroturystyki w gminach: Wola Uhruska i Włodawa, „Rocznik Naukowy”, t. 7: 2000, s. 61-76; taż, Przyrodnicze warunki rozwoju agroturystyki w gminach północnych Niziny Południowopodlaskiej, „Rocznik Naukowy”, t. 6: 1999, s. 163-188; D. Nałęcka, Agroturystyka w społeczno-ekonomicznym rozwoju środowiska wiejskiego, „Rocznik Naukowy”, t. 4: 1998, s. 163-164; J. Sikora, K. Buchta, Agroturystyka czynnikiem rozwoju wsi lubelskiej, „Rocznik Naukowy”, t. 7: 2000, s. 17-36; G. Godlewski, J. Żbikowski, Turystyka jako strategiczny aspekt rozwoju Białej Podlaskiej, „Rocznik Naukowy”, t. 9: 2002, s. $137-150$ 


\section{Podsumowanie}

B ialska Filia AWF działalność wydawniczą rozpoczęła w piątym roku Bistnienia. Nie było to zadanie łatwe - brakowało podstaw prawnych, odpowiednich środków, miejscowych oficyn wydawniczych i kompetentnych osób. W ciągu trzydziestu lat (1973-2002), w tym dziewiętnastu lat przerwy (1976-1994), na dorobek wydawniczy bialskiej Filii AWF złożyło się łącznie jedenaście zeszytów i dziesięć tomów, w tym jeden tom w angielskiej wersji językowej i jeden tom specjalny. Nie jest to dużo, ale ta peryferyjnie położona szkoła wyższa przeżywała różnorodne trudności organizacyjne. Ostatnie lata pokazały, że po długim okresie stagnacji uczelnia nadrabia zaległości. Wydając własne pismo, daje możliwość startu i promuje młodych pracowników nauki.

\section{Scientific periodicals of the Branch of Academy of Physical Education in Biała Podlaska in years 1973-2002}

Abstract

In years 1973-2002 Branch of Academy of Physical Education in Biała Podlaska was publishing two scientific periodicals. First of them was „Zeszyt Naukowy”, transformed later into „Zeszyt Naukowo-Metodyczny” (11 volumes had been published). Second was „Rocznik Naukowy” (10 volumes had been published). Content both periodicals presented results of researches made on Academy, from topics like physical education of children, agrotouristic and many others. 